\title{
The impact of an extreme flood in spring/summer 2010 on phytoplankton communities in oxbow lakes of the lower Vistula River, central Poland
}

\author{
Ewa A. Dembowska* \\ Department of Hydrobiology, Faculty of Biology and Environment Protection, Nicolaus Copernicus University, Lwowska 1, \\ 87-100 Toruń, Poland
}

Received 4 August 2016; Accepted 2 November 2016

\begin{abstract}
In 2010, central Europe was hit by a massive flood. The main objective of this study was to assess the impact of this natural disaster on phytoplankton communities in four oxbow lakes of the lower Vistula River. In order to explain changes caused by the flood, the data from the year 2010 were compared with the data from the previous year. In summer 2009, the abundance and biomass of phytoplankton as well as chlorophyll $a$ content in small isolated oxbow lakes were relatively low. Small nanoplankton flagellates prevailed. Much higher abundance and biomass of phytoplankton and chlorophyll $a$ content were recorded in a large oxbow lake, characterized by the predominance of filamentous cyanobacteria. After the flood wave, the abundance and biomass of phytoplankton in the small oxbow lakes increased dramatically (18 and 7 times, respectively), but the number of species decreased. Filamentous cyanobacteria (Dolichospermum), euglenophyta and dinoflagellates were identified. In the large oxbow lake, the number of species increased but the abundance and biomass of phytoplankton decreased (by approximately 60 and $75 \%$ ). There was a shift in dominant algal species. Cyanobacteria were replaced mainly by cryptophyta, small chlorophyta (Chlamydomonas) and xanthophyta (Heterothrix). The least significant changes were recorded in the Vistula River. Here, before and after the flood, the abundance and biomass of phytoplankton as well as chlorophyll $a$ content and the dominant algal species remained unchanged. The massive flood caused severe environmental stress, which disturbed phytoplankton development and led to shifts between clear water and turbid states in the lakes.
\end{abstract}

Key words: Floodplain lake / phytoplankton / species diversity / functional groups / flood wave

\section{Introduction}

River Flood Pulse theory (Junk et al., 1989) states that pulsing of river discharge is the most important environmental factor in floodplain ecosystems. According to this concept, river basins constitute an integral part of dynamic river systems, interconnected through hydrological and ecological processes. Systems of this kind are characterized by great diversity resulting from interactions between a flowing river, stagnant lakes and periodically flooded wetlands in the river valley. There is a constant exchange of energy and matter between land and water systems (Junk et al., 1989; Tockner et al., 2000).

Periods of flooding are followed by periods of hydrological drought. In the valleys of unregulated rivers, these phases occur in regular succession. Oxbow lakes are considered regular features of the valleys of large lowland

\footnotetext{
*Corresponding author: dembow@umk.p1
}

rivers. Typically, they are shallow and elongated, though sometimes have a horseshoe shape. They can be partly connected with the river or completely isolated. The width of connection between these water bodies depends both on the water level in the river and the morphology of the oxbow (Tockner et al., 1999; Ward et al., 2002). The immense morphological, hydrological and biocenotic diversity of these lakes ensures their great ecological potential.

Valleys of many large European rivers have been heavily transformed as a result of river regulation and construction of flood defenses (Dynesius and Nilsson, 1994; Makowski, 1998). In the last century, more than $80 \%$ of large European rivers were regulated. As a consequence, the isolation of oxbow lakes (limnophase) may last as long as several years, and sometimes longer. Owing to antiflood systems, water remains in the river channel even when its level is high. However, very high water inflow makes the river overflow and flood the valley causing major damage. 
Table 1. Morphometric data for the studied lakes.

\begin{tabular}{lcccc}
\hline & W1 & W1a & Ma & PD \\
\hline Geographical location & N 53 $01^{\prime} \mathrm{E} 18^{\circ} 39^{\prime}$ & N 53 $^{\circ} 01^{\prime} \mathrm{E} 18^{\circ} 39^{\prime}$ & N 53 $^{\circ} 00^{\prime} \mathrm{E} 18^{\circ} 34^{\prime}$ & $\mathrm{N} \mathrm{53}^{\circ} 01^{\prime} \mathrm{E} 18^{\circ} 30^{\prime}$ \\
Surface [ha] & 1.5 & 2.5 & 2.8 & 71 \\
Maximum depth [m] & 1.8 & 2.5 & 2.5 & 1 \\
Maximum length [m] & 140 & 220 & 640 & 1800 \\
Maximum width [m] & 67 & 40 & 61 & 390 \\
\hline
\end{tabular}

Phytoplankton communities in oxbow lakes follow a cyclical pattern of changes resulting from changing hydrological conditions. Hydrological changes affect the structure and productivity of these communities (Wojciechowska et al., 2005; Stević et al., 2013; Grabowska et al., 2014; Dembowska and Napiórkowski, 2015). During the potamophase, oxbow biocenosis is removed and partly replaced by river biocenosis. Phytoplankton biomass is low due to physical disturbances and a large share of abioseston, which impedes photosynthesis. During the limnophase, light conditions are improved due to slower water flow and the sedimentation of suspension. This promotes the development of indigenous phytoplankton and blooms of cyanobacteria (Bovo-Scomparin and Train, 2008; Mihaljević and Stević, 2011; O'Farell et al., 2014).

Phytoplankton studies should focus not only on the species composition but also on the community structure. Assessing the role of functional groups of phytoplankton seems particularly useful (Reynolds et al., 2002; Padisák et al., 2009). The evaluation of the dynamics of changes within the groups shows the rate of environmental change.

The main aim of this study was to investigate the influence of an extreme flood from the river Vistula in May 2010 on phytoplankton communities in shallow oxbow lakes located in Torun, lower Vistula valley. In order to evaluate the importance of the extreme conditions on the phytoplankton communities in 2010, the results were compared with those from 2009, obtained during the investigation carried under regular hydrological conditions.

The following hypotheses were analyzed:

(1) Changes in hydrological conditions in the oxbow lake cause changes in the phytoplankton biomass, species composition and functional groups. Functional groups of phytoplankton can be used to assess whether flood pulsing is a factor that stimulates or disturbs phytoplankton development.

(2) Within 1 to 2 months after the flood, algae carried by the river are deposited as sediment. Algal communities typical of oxbow lakes (found there before the limnophase) gradually recover.

\section{Materials and methods}

\section{Study area}

The study was conducted in four oxbow lakes of the lower Vistula River located in Torun, between 730 and
$742 \mathrm{~km}$ of the river course. Winnica 1 (W1), Winnica 1a (W1a) and Martówka (Ma) are shallow (1.8-2.5 m) and have a small surface area (1.5-2.8 ha). Lake Port Drzewny (PD) is shallow, but its surface area at the medium water level is 70.8 ha. All investigated lakes are located within a distance of $250-500 \mathrm{~m}$ from the river.

The studied lakes had different communities of vascular plants. The cover on lake W1, which appeared at the beginning of June, eventually covered its entire surface. Free floating plants included the following species: Spirodela polyrhiza (L.) Schleid., Salvinia natans (L.) All., and Lemna minor (L.). In lake Wla, submerged macrophytes included Ceratophyllum demersum L., Myriophyllum spicatum L., $M$. verticillatum $\mathrm{L}$. and Potamogeton spp. Plants with floating leaves such as Nuphar lutea (L.) Sibth. \& Sm. and Hydrocharis morsus-ranae $\mathrm{L}$. were found near the banks. In lake $\mathrm{Ma}$, the bottom was thickly covered with Ceratophyllum demersum L. The flora in lake Port Drzewny was poorly developed and consisted mainly of Elodea canadensis Michaux and Potamogeton spp. found near the banks. Morphometric data for all lakes are presented in Table 1.

\section{Methods}

Phytoplankton was collected in July and August 2009 (before the flood) and in July and August 2010 (after the flood). Sample collection sites were located in the central part of each lake. Plankton in the Vistula River (at $732 \mathrm{~km}$ of its course) was also analyzed. A total of 20 phytoplankton samples were collected from the lakes and the river during the research. For qualitative studies, the material was collected with a plankton net with a mesh diameter of $10 \mu \mathrm{m}$ from the water column, and preserved with formaldehyde. For quantitative analyses, non-concentrated samples were collected from beneath the surface, i.e. at a depth of about $0.5 \mathrm{~m}$. Material for quantitative analyses was immediately preserved with Lugol's solution ( $\mathrm{J}$ in $\mathrm{KJ}$ ). The following physicochemical parameters of water were also determined: temperature $\left(\mathrm{WT},{ }^{\circ} \mathrm{C}\right), \mathrm{pH}$, electrolytic conductivity $\left(\mathrm{EC}, \mu \mathrm{S} . \mathrm{cm}^{-1}\right)$ and the oxygen content (DO, mg. $\mathrm{L}^{-1}$; DO, \%), using a WTW MultiLine P4 multi-parameter probe. Water transparency (SD, m) was measured by Secchi disc. For chlorophyll $a\left(\mathrm{Chl} a, \mu \mathrm{g} . \mathrm{L}^{-1}\right)$ content, water was filtered through a Whatman $\mathrm{GF} / \mathrm{C}$ glass fiber filter and extracted with ethanol. Chl $a$ contents were measured and calculated according to the Nusch (1980) method. Absorbance was measured with a Jasco UV/VIS V-530 spectrophotometer. 


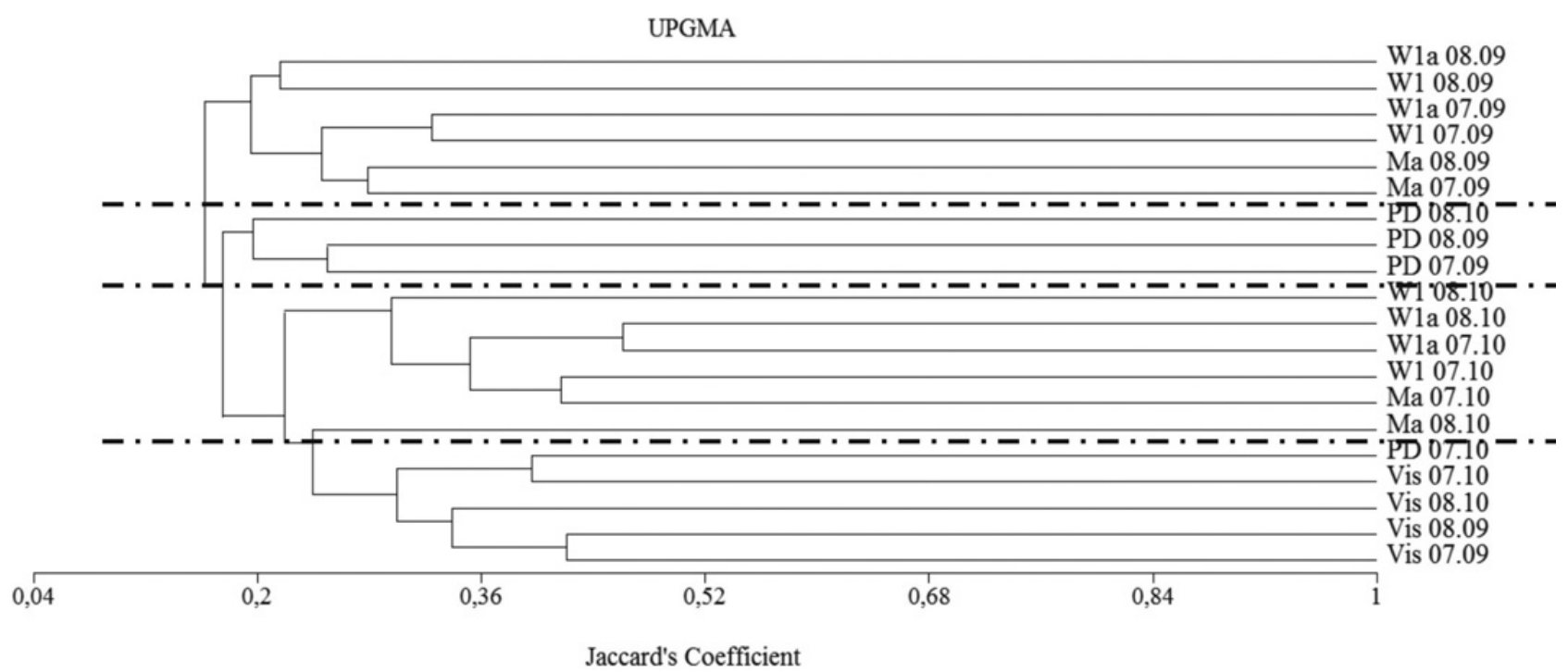

Fig. 1. Dendrogram of phytoplankton similarity in oxbow lakes and the Vistula River in the year preceding the flood (2009) and in the year of the flood (2010).

Phytoplankton species were identified using a light microscope (Nikon Alphaphot-2). To identify diatom species, samples were treated with $\mathrm{HCl}$ and about $30 \%$ $\mathrm{H}_{2} \mathrm{O}_{2}$. The abundance of algae was determined with the Utermöhl (1958) method, and the biomass with the volumetric method (Hillebrand et al., 1999; Sun and Liu, 2003), assuming that $1 \mathrm{~mm}^{3}$ of algae is equal to $1 \mathrm{mg}$. The abundance of each species is presented as the number of individual cells per liter $\left(\mathrm{N}\right.$, ind.. $\left.\mathrm{L}^{-1}\right)$. Biovolume $(\mathrm{B})$ was expressed as $\mathrm{mg} . \mathrm{L}^{-1}$ fresh mass. Dominant phytoplankton species were estimated from the percentage contribution of individual species to the total biomass. Only the species with a minimum of $5 \%$ contribution to the total biomass were considered dominant. Dominant species described in this paper were classified into functional groups, based on the studies by Reynolds et al. (2002); Reynolds (2006) and Padisák et al. (2009).

In order to assess similarity between phytoplankton communities (Jaccard's coefficient), species diversity (Shannon-Weaver, evenness) and the relationship between dominant species and environmental variables (CCA), MVSP 3.2 (multivariate statistical package, www.kovcomp.com/mvsp) was applied.

\section{Results}

Water levels in the years 2001-2009 were moderate. The average annual water level of the Vistula River in Torun within this period was $280 \mathrm{~cm}$ (low medium level). In May 2010, an extreme flood occurred. The maximum water level was recorded on May $24(856 \mathrm{~cm}$, flow $\left.5800 \mathrm{~m}^{3} \cdot \mathrm{s}^{-1}\right)$. The massive inflow of river water affected the quality of water in the analyzed oxbows, with water transparency and electrolytic conductivity changing the most significantly. In lakes $\mathrm{Ma}, \mathrm{W} 1$ and W1a, water transparency decreased dramatically in 2010 , while in lake PD, it increased by 1.5 times. In 2010, electrolytic conductivity in the Vistula and all oxbows was lower than in 2009. The largest decrease was observed in lake Ma: $970 \mu \mathrm{S} . \mathrm{cm}^{-1}$ in July 2009 and $923 \mu \mathrm{S} . \mathrm{cm}^{-1}$ in August 2009. In the following year, the values decreased further to $503 \mu \mathrm{S} . \mathrm{cm}^{-1}$ and $482 \mu \mathrm{S} . \mathrm{cm}^{-1}$. All physical and chemical parameters are presented in Table 2.

A total of 125 taxa of algae were identified. With 66 species, lakes Ma and PD were the richest in species. The species composition changed distinctly after the flood (Table 2). Thirty-eight algal taxa were identified in the Vistula in the year preceding the flood, and 47 in the following year. The lowest number of taxa was recorded in W1a: 31 before the flood and only 26 after the flood. In lakes $\mathrm{W} 1$ and Ma, the number of taxa also decreased after the flood. An increased number of species in 2010 was recorded only in lake PD (40 in 2009 and 48 in 2010).

Before the flood, the phytoplankton abundance in the small isolated oxbow lakes was low and ranged from $0.71910^{6}$ ind... $\mathrm{L}^{-1}$ (August 2009) in lake $\mathrm{Ma}$ to $1.57010^{6}$ ind... ${ }^{-1}$ (also August 2009) in lake W1a. The most abundant were nanoplankton flagellates (FGS $W 2, \quad X 2, \quad X 1, \quad Y$ ), cryptophyta (Cryptomonas spp., Plagioselmis nannoplanctica (H. Skuja) G. Novarino, I. A. N. Lucas \& S. Morrall), euglenophyta (Trachelomonas spp. of the Volvocinae group) and small chlorophyta (Chlamydomonas spp., Monoraphidium minutum (Nägeli) Komárková-Legnerová). Much higher phytoplankton abundance in August 2009 was noted in the large lake $\mathrm{PD}$, where it reached $17.88810^{6}$ ind... $\mathrm{L}^{-1}$. The predominance of filamentous cyanobacteria (Aphanizomenon flos-aquae Ralfs ex Bornet et Flahault, Planktothrix agardhii (Gomont) Anagnostidis et Komárek), centric diatoms (Actinocyclus normanii (W. Gregory ex Greville) Hustedt, Aulacoseira granulata (Ehrenberg) Simonsen), cryptophyta, euglenophyta, small chlorophyta and xantophyta Heterothrix stichococcoides (Pascher) P.C.Silva (FGs $D, H 1, J, P, S 1, W 2, Y$ ) was observed. 
Table 2. Average physico-chemical and biological parameters of oxbow lakes before 2009 and after the 2010 , flood.

\begin{tabular}{|c|c|c|c|c|c|c|c|c|c|c|}
\hline & \multicolumn{2}{|c|}{ Vistula } & \multicolumn{2}{|c|}{ W1 } & \multicolumn{2}{|c|}{ W1a } & \multicolumn{2}{|c|}{$\mathrm{Ma}$} & \multicolumn{2}{|c|}{$\mathrm{PD}$} \\
\hline & 2009 & 2010 & 2009 & 2010 & 2009 & 2010 & 2009 & 2010 & 2009 & 2010 \\
\hline$\overline{\mathrm{SD}}[\mathrm{m}]$ & - & - & 1.55 & 0.6 & 1.3 & 0.65 & 1.95 & 0.4 & 0.9 & 1.4 \\
\hline $\mathrm{DO}\left[\mathrm{mg} . \mathrm{L}^{-1}\right]$ & 5.38 & 7.03 & 1.51 & 4.57 & 2.48 & 4.63 & 7.12 & 5.09 & 6.06 & 7.75 \\
\hline DO $[\%]$ & 61.3 & 82.4 & 16.7 & 52.9 & 28.0 & 52.0 & 82.8 & 59.0 & 65.9 & 90.0 \\
\hline $\mathrm{WT}\left[{ }^{\circ} \mathrm{C}\right]$ & 21.8 & 22.3 & 18.6 & 20.4 & 19.6 & 20.9 & 23.4 & 21.5 & 22.4 & 21.2 \\
\hline $\mathrm{pH}$ & 8.16 & 8.32 & 7.75 & 7.89 & 7.74 & 7.97 & 8.08 & 8.17 & 8.34 & 8.18 \\
\hline $\mathrm{EC}\left[\mu \mathrm{S} . \mathrm{cm}^{-1}\right]$ & 572 & 483 & 780 & 703 & 789 & 651 & 947 & 493 & 683 & 620 \\
\hline Chl $a\left[\mu \mathrm{g} . \mathrm{L}^{-1}\right]$ & 17.15 & 31.79 & 13.80 & 98.78 & 11.92 & 93.56 & 6.68 & 71.26 & 33.77 & 26.69 \\
\hline $\mathrm{N}$ & 38 & 47 & 47 & 38 & 31 & 26 & 43 & 39 & 40 & 48 \\
\hline $\mathrm{N}\left[10^{6}\right.$ ind... $\left.\mathrm{L}^{-1}\right]$ & 1.177 & 1.591 & 0.893 & 6.861 & 1.300 & 23.296 & 0.435 & 5.466 & 10.780 & 4.623 \\
\hline $\mathrm{B}\left[\mathrm{mg} . \mathrm{L}^{-1}\right]$ & 1.440 & 1.700 & 4.405 & 8.653 & 1.963 & 13.015 & 1.434 & 9.542 & 12.558 & 3.272 \\
\hline $\mathrm{H}^{\prime}$ & 2.598 & 2.414 & 2.536 & 2.367 & 2.092 & 1.370 & 2.125 & 2.695 & 2.168 & 2.433 \\
\hline e & 0.714 & 0.627 & 0.659 & 0.651 & 0.609 & 0.420 & 0.565 & 0.735 & 0.588 & 0.629 \\
\hline
\end{tabular}

SD, Secchi disc visibility; DO, dissolved oxygen content; WT, water temperature; $\mathrm{pH}$, reaction; EC, electrolytic conductivity; Chl $a$, chlorophyll a content; n, number of phytoplankton taxa; N, phytoplankton abundance; B, phytoplankton biomass; H', Shannon-Weaver index; e, evenness.

Phytoplankton abundance in the Vistula was similar to that of the small oxbows: $0.55210^{6}$ ind... $\mathrm{L}^{-1}$ in July 2009 and $1.80210^{6}$ ind.... ${ }^{-1}$ in August 2009. However, dominant algae were different: centric diatoms, Cryptomonas erosa Ehrenberg and coccal chlorophyta (FGs $C, D, J, X 1$ ) were the most abundant.

In 2010, after the flood, phytoplankton abundance in small isolated oxbow lakes increased dramatically. In lake Ma, the highest abundance was recorded in August (7.800 $10^{6}$ ind... $\left.^{-1}\right)$, in lakes W1 and W1a, in July $\left(12.72410^{6}\right.$ ind... $\mathrm{L}^{-1}$ and $30.81410^{6}$ ind... $\mathrm{L}^{-1}$, respectively). Dominant algal species were different. In lake $\mathrm{Ma}$, the proportion of small nanoplankton flagellates ( $Y$, $W 2$ ) was still high, but cyanobacteria Dolichospermum flos-aquae (Brébisson ex Bornet \& Flahault) P.Wacklin, L.Hoffmann et J.Komárek (FG HI) were also abundant.

In $\mathrm{W} 1$ and W1a, previously dominant cryptophyta and Chlamydomonas spp. (FGs $Y, X 2$ ) were accompanied by abundant euglenophyta (W2), centric diatoms (C) and chrysophyta Synura uvella Ehrenberg (Ws). In PD, phytoplankton abundance dropped to $5.46510^{6}$ ind... $\mathrm{L}^{-1}$ in July 2010 and $3.78010^{6}$ ind... $^{-1}$ in August 2010 (similar to the value recorded in July 2009). The dominant algal species included cryptophyta, Chlamydomonas spp., Heterothrix stichococcoides, and nanoplankton cyanobacteria Synechocystis aquatilis Sauvageau (FGs $Y$, $X 2, X 1)$.

In the Vistula, phytoplankton abundance remained unchanged $\left(2.49110^{6}\right.$ ind... $^{-1}$ in July 2010 and $0.69010^{6}$ ind... $\mathrm{L}^{-1}$ in August 2010). Moreover, centric diatoms and coccal chlorophyta were still predominant (FGs $C, D, J, X 1)$. All dominant FGs are presented in Table 3 .

Before the flood, the average phytoplankton biomass in the small oxbow lakes was low and ranged from $1.434 \mathrm{mg} . \mathrm{L}^{-1}$ in lake Ma to $4.405 \mathrm{mg} . \mathrm{L}^{-1}$ in W1. In lake $\mathrm{Ma}$, predominant species included cryptophyta (Cryptomonas spp., Plagioselmis nannoplanctica), chlorophyta (Chlamydomonas spp.) and chrysophyta Uroglena sp., in lake W1, chrysophyta Uroglena sp, and in lake W1a,
Aphanizomenon flos-aquae, Planktothrix agardhii and cryptophyta. At the same time, water bloom was observed in lake PD and phytoplankton biomass ranged from 6.255 to $18.860 \mathrm{mg} . \mathrm{L}^{-1}$. Cyanobacteria (Aphanizomenon flos-aquae, Microcystis wesenbergii (Komárek) Komárek ex Komárek, Planktothrix agardhii), centric diatoms (mainly Actinocyclus normanii) and cryptophyta had the greatest contribution to the biomass.

Phytoplankton biomass in the Vistula was low and ranged from $0.639 \mathrm{mg} . \mathrm{L}^{-1}$ to $2.241 \mathrm{mg} . \mathrm{L}^{-1}$. Predominant algae belonged to centric diatoms (Cyclotella meneghiniana Kützing and Actinocyclus normanii) and coccal chlorophyta (Pediastrum boryanum (Turpin) Meneghin, $P$. duplex Meyen, P. simplex Meyen and Desmodesmus communis (E. Hegewald) E. Hegewald).

In 2010, phytoplankton biomass in the small oxbow lakes increased significantly. In all lakes, its maximum value was recorded a month after the flood wave, i.e. in July: $11.100 \mathrm{mg} . \mathrm{L}^{-1}$ in Ma, $15.683 \mathrm{mg} . \mathrm{L}^{-1}$ in $\mathrm{W} 1$ and $17.119 \mathrm{mg} . \mathrm{L}^{-1}$ in W1a. During the next month, the biomass dropped by almost $30 \%$ in Ma, by $90 \%$ in W1 and by about $50 \%$ in W1a. After the flood, Dolichospermum flos-aquae, Cyclotella meneghiniana, Peridinium cinctum (O.F.Müller) Ehrenberg, Euglena spp. and Trachelomonas hispida (Perty) F.Stein dominated in the biomass of lake Ma. In W1 and W1a, Chlamydomonas spp., Peridinium cinctum, Euglena spp. and Cyclotella meneghiniana prevailed.

In lake $\mathrm{PD}$, the biomass decreased to $4.656 \mathrm{mg} . \mathrm{L}^{-1}$ in July 2010, and to $1.888 \mathrm{mg} \cdot \mathrm{L}^{-1}$ in August 2010. Predominant species belonged to cryptophyta and chlorophytes of the genus Chlamydomonas. In the Vistula, the phytoplankton biomass was similar to that recorded the previous year $\left(2.685 \mathrm{mg} . \mathrm{L}^{-1}\right.$ in July 2010 and $0.715 \mathrm{mg} . \mathrm{L}^{-1}$ in August 2010). Centric diatoms (Melosira varians C.Agardh) and coccal chlorophyta (Coelastrum microporum Nägeli in A.Braun, Pediastrum duplex, Desmodesmus communis) were predominant.

Jaccard similarity analysis (Fig. 1) indicates a close similarity of the three small isolated lakes before flooding 
Table 3. Functional groups of phytoplankton, representative species and their dominance based on abundance $>5 \%$ in at least single samples in total abundance before 2009 and after the 2010, flood.

\begin{tabular}{|c|c|c|c|}
\hline$F G$ & Main representatives & Dominance before flood & Dominance after flood \\
\hline $\bar{C}$ & Cyclotella meneghiniana Kützing & Vistula & Ma; W1 \\
\hline$D$ & Actinocyclus normanii & W1; PD & \\
\hline$E$ & Dinobryon divergens Imhoff & & \\
\hline F & Oocystis lacustris Chodat & PD & \\
\hline$H 1$ & $\begin{array}{l}\text { Aphanizomenon flos-aquae, Dolichospermum flos-aquae, Dolichospermum } \\
\text { heterosporum (Nygaard) P. Wacklin, L. Hoffmann \& J. Komárek, } \\
\text { Dolichospermum sp. div. }\end{array}$ & W1; PD & Ma \\
\hline$J$ & $\begin{array}{l}\text { Coelastrum astroideum De Notaris, C. microporum Nägeli, Crucigenia/ } \\
\text { Crucigeniella sp. div., Desmodesmus communis (E. Hegewald) } \\
\text { E. Hegewald, D. denticulatus (Lagerheim) S. S. An, T. Friedl \& } \\
\text { E. Hegewald, D. intermedius (Chodat) E. Hegewald, Pediastrum boryanum } \\
\text { (Turpin) Meneghini, P. duplex Meyen, Tetrastrum glabrum (Y. V. Roll) } \\
\text { Ahlstrom \& Tiffany }\end{array}$ & Vistula; Ma; W1; PD & Vistula; Ma; PD \\
\hline Lo & $\begin{array}{l}\text { Peridinium cinctum (O. F. Müller) Ehrenberg, Peridiniopsis cunningtonii } \\
\text { Lemmermann }\end{array}$ & & \\
\hline$M P$ & Cymbella sp., Navicula tripunctata (O. F. Müller) Bory, Navicula sp. div. & W1a & \\
\hline$P$ & $\begin{array}{l}\text { Aulacoseira granulata (Ehrenberg) Simonsen, Fragilaria crotonensis } \\
\text { Kitton, F. capucina Desmazières }\end{array}$ & PD & Vistula \\
\hline S1 & $\begin{array}{l}\text { Planktothrix agardhii (Gomont) Anagnostidis \& Komárek, } \\
\text { Pseudanabena limnetica (Lemmermann) Komárek }\end{array}$ & W1a; PD & \\
\hline$W 1$ & Euglena spp., Lepocinclis acus (O. F. Müller) B. Marin \& Melko & & $\mathrm{Ma}$ \\
\hline$W 2$ & $\begin{array}{l}\text { Trachelomonas volvocina (Ehrenberg) Ehrenberg, T. volvocinopsis } \\
\text { Svirenko, Trachelomonas sp. div. }\end{array}$ & & $\mathrm{Ma} ; \mathrm{PD}$ \\
\hline$W s$ & Synura uvella & & W1; W1a \\
\hline$X 1$ & $\begin{array}{l}\text { Monoraphidium contortum (Thuret) Komárková-Legnerová, } \\
\text { Monoraphidium grifithii (Berk.) Komárková-Legnerová, } \\
\text { M. minutum, Synechocystis aquatilis }\end{array}$ & W1 & Vistula; W1; Ma; PD; \\
\hline$X 2$ & Plagioselmis nannoplanctica, Chlamydomonas spp. & All stations & All stations \\
\hline$Y$ & $\begin{array}{l}\text { Cryptomonas erosa, C. marssonii Skuja, C. obovata Skuja, } \\
\text { C. ovata } \text { Ehrenberg, C. rostratiformis Skuja }\end{array}$ & All stations & All stations \\
\hline ? & Heterothrix stichococcoides & Vistula; PD & Vistula; PD \\
\hline
\end{tabular}

(2009). The same lakes after flooding also constitute a group with a high similarity coefficient. Samples collected from the Vistula (regardless of hydrological conditions) are yet another group with the highest similarity coefficient.

\section{Discussion}

In summer 2009, average water levels were recorded in the river based on the data from the last 10 years. Lakes $\mathrm{Ma}, \mathrm{W} 1$ and $\mathrm{W} 1 \mathrm{a}$ were isolated from the river. In lake W1, a thick layer of pleustophyta disturbed phytoplankton development (Dembowska, 2015). The bottoms of lakes Ma and W1a were covered with dense submerged vegetation, mainly Ceratophyllum demersum. Phytoplankton growth was limited, and both phytoplankton biomass and chlorophyll $a$ content were low. Lakes Ma, W1 and Wla had characteristics of shallow macrophyte lakes (Scheffer and Jeppesen, 1998), in which competition and allelopathic interactions between macrophytes and phytoplankton result in high water transparency (Van Donk et al., 1993). Lake PD was connected to the river. The submerged vegetation was found only near the shores. Phytoplankton grew abundantly, with annual summer blooms of Aphanizomenon flos-aquae (Dembowska et al., 2012).

The hydrological state, which lasted for several years changed in 2010. Central Europe (Austria, Czech Republic, Germany, Poland, Serbia, Slovakia, Ukraine and Hungary) was hit by a massive flood. It is expected that climate change may increase the frequency and extent of these natural disasters (IPCC, 2012).

In the study area (the lower course of the Vistula River in Toruń), the highest water level was recorded in the evening of May 23, $2010(859 \mathrm{~cm})$. The alert level $(650 \mathrm{~cm})$ was exceeded by more than $2 \mathrm{~m}$. On June 10, the flood returned, but this time the water level was lower $(790 \mathrm{~cm})$. The river valley was under water. The oxbow lakes Ma, W1 and W1a, which had been isolated from the river for many years (Dembowska, 2015) were also flooded.

The flood drastically changed environmental conditions in the studied lakes. Electrolytic conductivity decreased as a result of water dilution with floodwater. In three lakes, it decreased by only around $10-20 \%$. However, in lake Ma, it dropped by $50 \%$. The lake is actually a pond located in the center of the town and the impact of storm water is the strongest here. Its high $\mathrm{EC}$ is usually caused by the inflow of saline water rich in chlorides during spring thaw. 


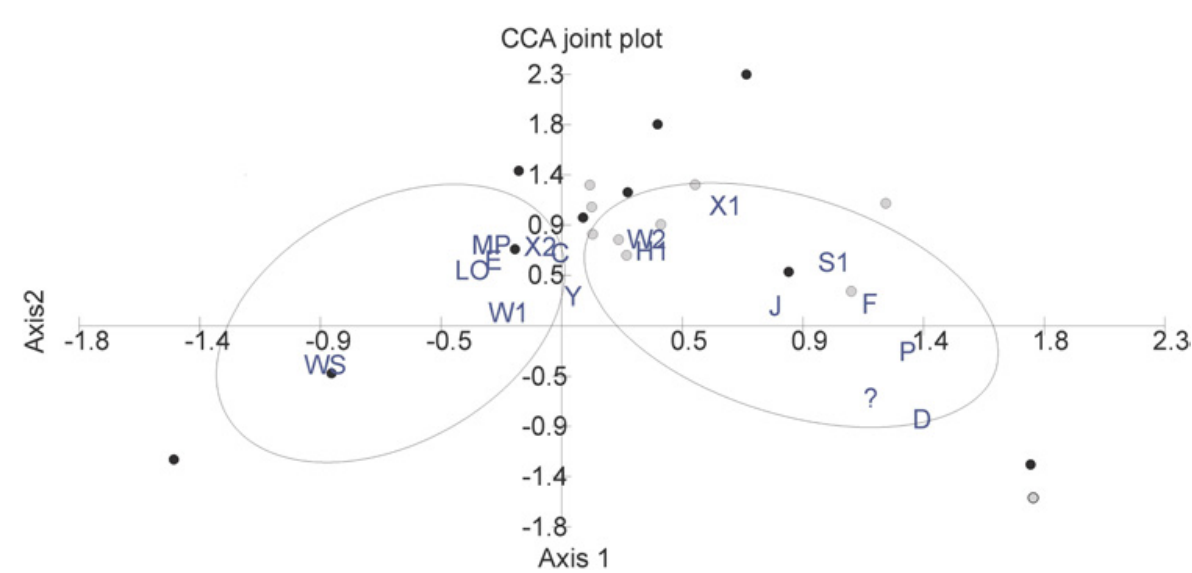

Fig. 2. Results of CCA analysis. Symbols (C, D, E, F, H1, J, LO, MP, P, S1, W1, W2, WS, X1, X2, Y, ?; see Table 3) indicate predominant FGs of phytoplankton. Gray circles represent dates before the flood, black circles, after the flood. The first axis explains $22.051 \%$ of the variation, the other axis explains $12.846 \%$ of variability.

In lakes $\mathrm{Ma}, \mathrm{W} 1$ and $\mathrm{W} 1 \mathrm{a}$, isolated from the river before the flood, water transparency decreased significantly after flooding (approx. 0.4-0.65 m Secchi disc visibility). Flood water carries large amounts of inorganic suspended matter (Wetzel, 2001). This limits light penetration efficiency and impedes the development of primary producers (phytoplankton, submerged macrophytes and periphytic algae), especially in the initial phase of the flood. Previous studies (Huszar and Reynolds, 1997; Train and Rodrigues, 1998) indicate that during flooding, phytoplankton abundance and biomass in oxbows is low but species diversity is the highest (Huszar and Reynolds, 1997; Wojciechowska et al., 2005).

Better oxygen saturation was recorded in the lakes after the flood. This may have been caused by good oxygenation of flood water. Moreover, increased phytoplankton abundance and biomass may have also led to better oxygenation of the water in the studied lakes. Higher primary production is also connected with a larger amount of produced oxygen.

Extreme flooding of rivers significantly changes species communities (Follner et al. 2010). After the flood of the river Vistula in spring/summer 2010, the phytoplankton species composition also changed. Cluster analysis and CCA analysis indicated that phytoplankton communities changed in all the studied water bodies (Fig. 1, Fig. 2). In addition, the species diversity indices (Shannon-Weaver index and evenness) changed as well: in lake Ma, they increased (Table 2), in the Vistula and lakes W1 and $\mathrm{PD}$, they remained almost the same and in $\mathrm{W} 1 \mathrm{a}$, they decreased. In W1a, they may stem from the fact that the population of macrophytes was damaged. Macrophytes constituted a suitable substrate for periphytic algae, common in the water column. Lack of substrate for periphyton reduced diversity (lower diversity indices).

For 1 or 2 months following the flood, phytoplankton can develop rapidly (Schemel et al., 2004; Wojciechowska et al., 2005). In this study, abundance and biomass of phytoplankton in the investigated lakes were more than ten times higher. The share of cyanobacteria in phytoplankton also increased. The success of phytoplankton is due to several factors.

Firstly, violent flooding destroys macrophytes, which are natural competition for phytoplankton (Bakker and Hilt, 2016). Later, suspended matter prevents the restoration of the vascular plant community. Secondly, phytoplankton spores and cysts, inactivated in bottom sediments, are revived. This applies particularly to Cyanobacteria akinetes, which retain the ability to germinate for many years. Cyanobacteria can grow faster under poorer lighting conditions than eukaryotic algae (Mur et al., 1999). Thirdly, a smaller share of Cladocerans in zooplankton may be another reason. According to Napiórkowski and Napiórkowska (2014), there was an 18 -fold decrease in the abundance of crustacean zooplankton in the studied oxbow lakes. Although these authors noted a 15-fold increase in the abundance of rotifera, these small forms may only impair the development of the smallest pico- and nanoplankton. They do not affect the development of large forms of phytoplankton.

In lake PD, the reverse situation was observed: after the flood water transparency increased (up to $1.8 \mathrm{~m}$ in August 2010). Lake PD differs significantly from the other studied oxbows. It is large (surface area $71 \mathrm{ha}$ ), very shallow (average depth $1.5 \mathrm{~m}$ ), and is connected to the Vistula. Before the flood, Aphanizomenon flos-aquae blooms were a regular occurrence. Every summer, water transparency was low, while phytoplankton biomass and chlorophyll $a$ content were high (Dembowska et al., 2012). In this lake, spring and summer floods in 2010 impeded phytoplankton development. Similarly, a reduction of phytoplankton biomass during the potamophase was recorded in lake Sakadaš in the Danube valley by Mihaljević et al. (2009). Immediately after the flood, picoplankton cyanobacteria species Synechocystis aquatilis developed rapidly. However, due to the small cell size, their biomass was low. Originally, this species was included in the functional group $Z$ (Reynolds et al., 2002), but because of its habitat it is now classified in group $X 1$ (de Melo and Huszar, 2000). 
Flooding prevented another algal bloom by removing algae and introducing water without cyanobacteria. Cyanobacteria of the order Nostocales, sensitive to mixing water, are replaced by algae which can tolerate such conditions. A similar mechanism was confirmed by Mihaljević et al. $(2010,2013)$ in lake Sakadaš. A shift from a turbid state to clear water state was the result of extreme flooding. However, it is expected that the studied ecosystems will return to previous states in response to various hydrological impacts. A similar pattern was observed in the oxbow lake of the Danube River (Mihaljević and Stević, 2011). This research shows that after just 1 to 2 months, phytoplankton communities in the river returned to the state typical of moderate water levels. The phytoplankton number, biomass and biodiversity indices were similar in both years.

\section{Summary and conclusions}

Studies on the effects of extreme flooding of the Vistula in 2010 on phytoplankton in the oxbow lakes indicate changes in their ecological states. The low abundance and biomass of phytoplankton and low Chl $a$ content were typical of a clear water state in lakes normally isolated from the river. Extreme flooding caused severe environmental stress, which affected phytoplankton growth. In three lakes, a clear water state with the dominance of submerged macrophytes changed into a turbid state with the dominance of planktonic algae. In one lake, a turbid water state shifted into a clear water state. The results indicate that extreme flooding can lead to changes in alternative states of oxbow lakes. Further research should analyze whether and when the studied oxbow lakes will return to the states from before the flood.

Acknowledgements. The author thank anonymous reviewers for valuable comments.

\section{References}

Bakker E.S. and Hilt S., 2016. Impact of water-level fluctuations on cyanobacterial blooms: options for management. Aquat. Ecol., 50, 485-498.

Bovo-Scomparin V.M. and Train S., 2008. Long-term variability of the phytoplankton community in an isolated floodplain lake of the Ivinhema River State Park, Brazil. Hydrobiologia, 610, 331-344.

Dembowska E., 2015. Seasonal variation in phytoplankton and aquatic plants in floodplain lakes (lower Vistula River, Poland). Wetlands. Ecol. Manage., 23, 535-549.

Dembowska E. and Napiórkowski P., 2015. A case study of the planktonic communities in two hydrologically different oxbow lakes, Vistula River, Central Poland. J. Limnol., 74, 346-357.

Dembowska E., Głogowska B. and Dąbrowski K., 2012. Dynamics of algae communities in an oxbow lake (Vistula River, Poland). Arch. Pol. Fish., 20, 27-37. de Melo S. and Huszar V.L.M., 2000. Phytoplankton in an Amazonian flood-plain lake (Lago Batata, Brasil): diel variation and species strategies. J. Plankton Res., 22, 63-76.

Dynesius M. and Nilsson C., 1994. Fragmentation and flow regulation of river systems in the Northern Third of the World. Science, 266, 753-762.

Follner K., Hofacker A., Glaeser J., Dziock F., Gerisch M., Foeckler F., Ilg Ch., Schanowski A., Scholza M. and Henle K., 2010. Accurate environmental bioindication in floodplains in spite of an extreme flood event. River Res. Applic., 26, 877-886.

Grabowska M., Glińska-Lewczuk K., Obolewski K., Burandt P., Kobus S., Dunalska J., Kujawa R., Goździejewska A. and Skrzypczak A., 2014. Effects of hydrological and physicochemical factors on phytoplankton communities in floodplain lakes. Pol. J. Environ. Stud., 23, 713-725.

Hillebrand H., Dürselen C., Kirschtel D., Pollingher U. and Zohary T., 1999. Biovolume calculation for pelagic and benthic microalgae. J. Phycol., 35, 403-424.

Huszar V.L.M. and Reynolds C.S., 1997. Phytoplankton periodicity and sequences of dominance in an Amazonian flood-plain lake (Lago Batata, Pará, Brasil): responses to gradual environmental change. Hydrobiologia, 346, 169-181.

IPCC, 2012. Managing the risks of extreme events and disasters to advance climate change adaptation. In: Field C.B., Barros V., Stocker T.F., Qin D., Dokken D.J., Ebi K.L., Mastrandrea M.D., Mach K.J., Plattner G.-K., Allen S.K., Tignor M. and Midgley P.M. (eds.), A Special Report of Working Groups I and II of the Intergovernmental Panel on Climate Change, Cambridge University Press, Cambridge, $582 \mathrm{p}$.

Junk W.J., Bayley P.B. and Sparks R.E., 1989. The flood pulse concept in river-floodplain systems. In: Dodge D.P. (ed.), Proceedings of the International Large River Symposium. Canadian Special Publication of Fisheries and Aquatic Sciences, Dept. of Fisheries and Oceans, Ottawa, 106, $110-127$.

Makowski J., 1998. Wały przeciwpowodziowe dolnej Wisły, historyczne kształtowanie, obecny stan i zachowanie w czasie znacznych wezbrań. Część druga: odcinek od Torunia do Białej Góry. Wydawnictwo Instytutu Budownictwa Wodnego PAN, Biblioteka Naukowa Hydrotechnika, Gdańsk, 469 p. (in Polish).

Mihaljević M. and Stević F., 2011. Cyanobacterial blooms in a temperate river-floodplain ecosystem: the importance of hydrological extremes. Aquat. Ecol., 45, 335-349.

Mihaljević M., Stević F., Horvatić J. and Hackenberger Kutuzovic B., 2009. Dual impact of the flood pulses on the phytoplankton assemblages in a Danubian floodplain lake (Kopački Rit Nature Park, Croatia). Hydrobiologia, 618, 77-88.

Mihaljević M., Špoljarić D., Stević F., Cvijanović V. and Hackenberger Kutuzović B., 2010. The influence of extreme floods from the River Danube in 2006 on phytoplankton communities in a floodplain lake: shift to a clear state. Limnologica, 40, 260-268.

Mihaljević M., Pfeiffer T.Ž., Stević F. and Špoljarić D., 2013. Dynamics of phytoplankton and periphytic algae in a Danubian floodplain lake: a comparative study under 
altered hydrological conditions. Fres. Environ. Bull., 22, 2516-2523.

Mur L.R., Skulberg O.M., Utkilen H., 1999. Cyanobacteria in the environment. In: Chorus I. and Bartram J. (eds.), Toxic Cyanobacteria in Water: A Guide to Their Public Health Consequences, Monitoring and Management, E\&FN Spon on behalf of WHO, London, pp. 15-40.

Napiórkowski P. and Napiórkowska T., 2014. The impact of catastrophic flooding on zooplankton. Pol. J. Environ. Stud., 23, 409-417.

Nusch E.A., 1980. Comparison of different methods for chlorophyll and phaeopigment. Arch. Hydrobiol. Beih. Ergebn. Limno., 14, 14-16.

O'Farrell I., Vinocur A. and de Tezanos Pinto P., 2014. Longterm study of bloom-forming cyanobacteria in a highly fluctuating vegetated floodplain lake: a morpho-functional approach. Hydrobiologia, 752, 91-102.

Padisák J., Crossetti L.O. and Naselli-Flores L., 2009. Use and misuse in the application of the phytoplankton functional classification: a critical review with updates. Hydrobiologia, $621,1-19$.

Reynolds C.S., 2006. Ecology of Phytoplankton, Cambridge University Press, Cambridge, 535 p.

Reynolds C.S., Huszar V., Kruk C., Naselli-Flores L. and Melo S., 2002. Towards a functional classification of the freshwater phytoplankton. J. Plankton Res., 24, 417-428.

Scheffer M. and Jeppesen E., 1998. Alternative stable state. In: Scheffer M. (ed.), Ecology of Shallow Lakes, Chapman and Hall, London.

Schemel L.E., Sommer T.R., Müller-Solger A.B. and Harrell W.C., 2004. Hydrologic variability, water chemistry, and phytoplankton biomass in a large floodplain of the Sacramento River, CA, U.S.A. Hydrobiologia, 513, 129-139.
Stević F., Mihaljević M. and Špoljarić D., 2013. Changes of phytoplankton functional groups in a floodplain lake associated with hydrological perturbations. Hydrobiologia, 709, 143-158.

Sun J. and Liu D., 2003. Geometric models for calculating cell biovolume and surface area for phytoplankton. J. Plankton Res., 25, 1331-1346.

Tockner K., Schiemer F., Baumgartner C., Kum G., Weigand E., Zweimuller I. and Ward J.V., 1999. The Danube restoration project: species diversity patterns across connectivity gradients in the floodplain system. Regul. Rivers. Res. Mgtm., 15, 245-258.

Tockner K., Malard F. and Ward J.V., 2000. An extension of the flood pulse concept. Hydrol. Process., 14, 2861-2883.

Train S. and Rodrigues L.C., 1998. Temporal fluctuations of the phytoplankton community of the Baía River, in the upper Paraná River floodplain, Mato Grosso do Sul, Brazil. Hydrobiologia, 361, 125-134.

Utermöhl H., 1958. Zur vervollkommnung der quantitativen phytoplankton methodik. Mitt. Int. Verein. Theor. Angew. Limnol., 9, 1-38.

van Donk E., Gulati R.D., Iedema A. and Meulemans J.T., 1993. Macrophyte-related shifts in the nitrogen and phosphoruscontents of the different trophic levels in a biomanipulated shallow lake. Hydrobiologia, 251, 19-26.

Ward J.V., Tockner K., Arscott D.B. and Claret C., 2002. Riverine landscape diversity. Freshw. Biology, 47, 517-539.

Wetzel R., 2001. Limnology: Lake and River Ecosystems, Academic Press, San Diego, 1006 p.

Wojciechowska W., Pasztaleniec A., Solis M., Turczyński M. and Dawidek J., 2005. Phytoplankton of two river lakes in relation to flooding period (River Bug, eastern Poland). Pol. J. Ecol., 53, 419-425. 